\title{
Accelerating the research approach to Ziegler-Natta catalysts
}

\author{
Vincenzo Busico $^{* 1,2}$, Roberta Cipullo ${ }^{1,2}$, Alessio Mingione ${ }^{2}$, and Luca Rongo ${ }^{1, \#}$ \\ ${ }^{1}$ Department of Chemical Sciences, Federico II University of Naples, Via Cintia, 80126 Naples \\ (Italy) \\ ${ }^{2}$ HTExplore s.r.l., Via R. Morandi 12, 80124 Naples (Italy) \\ ${ }^{\#}$ Current address: SABIC Europe, NL-6160 AH Geleen, The Netherlands
}

*Corresponding Author. E-mail: busico@unina.it

\section{SUPPORTING INFORMATION}

\section{PPR propene polymerization protocol}

Prior to the execution of a library, the PPR modules undergo 'bake-and-purge' cycles overnight ( $8 \mathrm{~h}$ at $90-140^{\circ} \mathrm{C}$ with intermittent dry $\mathrm{N}_{2}$ flow), to remove any contaminants and left-overs from previous experiments. After cooling to glove-box temperature, the stir tops are taken off, and the 48 cells are fitted with disposable $10 \mathrm{~mL}$ glass inserts (pre-weighed in a Bohdan Balance Automator) and polyether ether ketone (PEEK) stir paddles. The stir tops are then set back in place, the modules are loaded with proper amounts of heptane diluent, $\mathrm{AlEt}_{3}$ scavenger, and $\mathrm{H}_{2}\left(p\left(\mathrm{H}_{2}\right)=0.20\right.$ bar), thermostated at $70^{\circ} \mathrm{C}$, and brought to the operating pressure with propene. At this point, the catalyst injection sequence is started; aliquots of a heptane 'chaser', a solution of $\mathrm{AlEt}_{3} / \mathrm{dialkyl}^{-}$ dimethoxysilane cocatalyst in heptane (pre-contacted in a $1.2 \mathrm{~mL}$ glass vial for $1.5 \mathrm{~min}$ ), a hydrocarbon slurry of the precatalyst $(0.10 \mathrm{mg})$, and a heptane 'buffer', all separated by nitrogen gaps, are uploaded by the slurry needle and subsequently injected into the cell of destination, thus starting the reaction. Inside each cell, the following reaction conditions are attained: hydrocarbon diluent, $5.0 \mathrm{~mL} ;[\mathrm{Al}]=2.6 \mathrm{mM} ;[\mathrm{Al}] /[\mathrm{Ti}]=195 ;[\mathrm{Al}] /[\mathrm{Si}]=20$. Polymerization is left to proceed under stirring $(800 \mathrm{rpm})$ at constant pressure by feeding propene $\left(p\left(\mathrm{C}_{3} \mathrm{H}_{6}\right)=4.5 \mathrm{bar}\right)$ on demand, and quenched after $30 \mathrm{~min}$ by over-pressurizing the cell with dry air. Once all cells have been quenched, the modules are cooled down and vented, the stir-tops are removed, and the glass inserts 
containing the reaction phase are taken out and transferred to a Genevac EZ2-Plus centrifugal evaporator, where all volatiles are distilled out and the polymers are thoroughly dried under vacuum overnight. Reaction yields are double-checked against on-line monomer conversion measurements by robotically weighing the dry polymers while still in the reaction vials, subtracting the prerecorded tare. Polymer aliquots are then sent to the characterizations. 

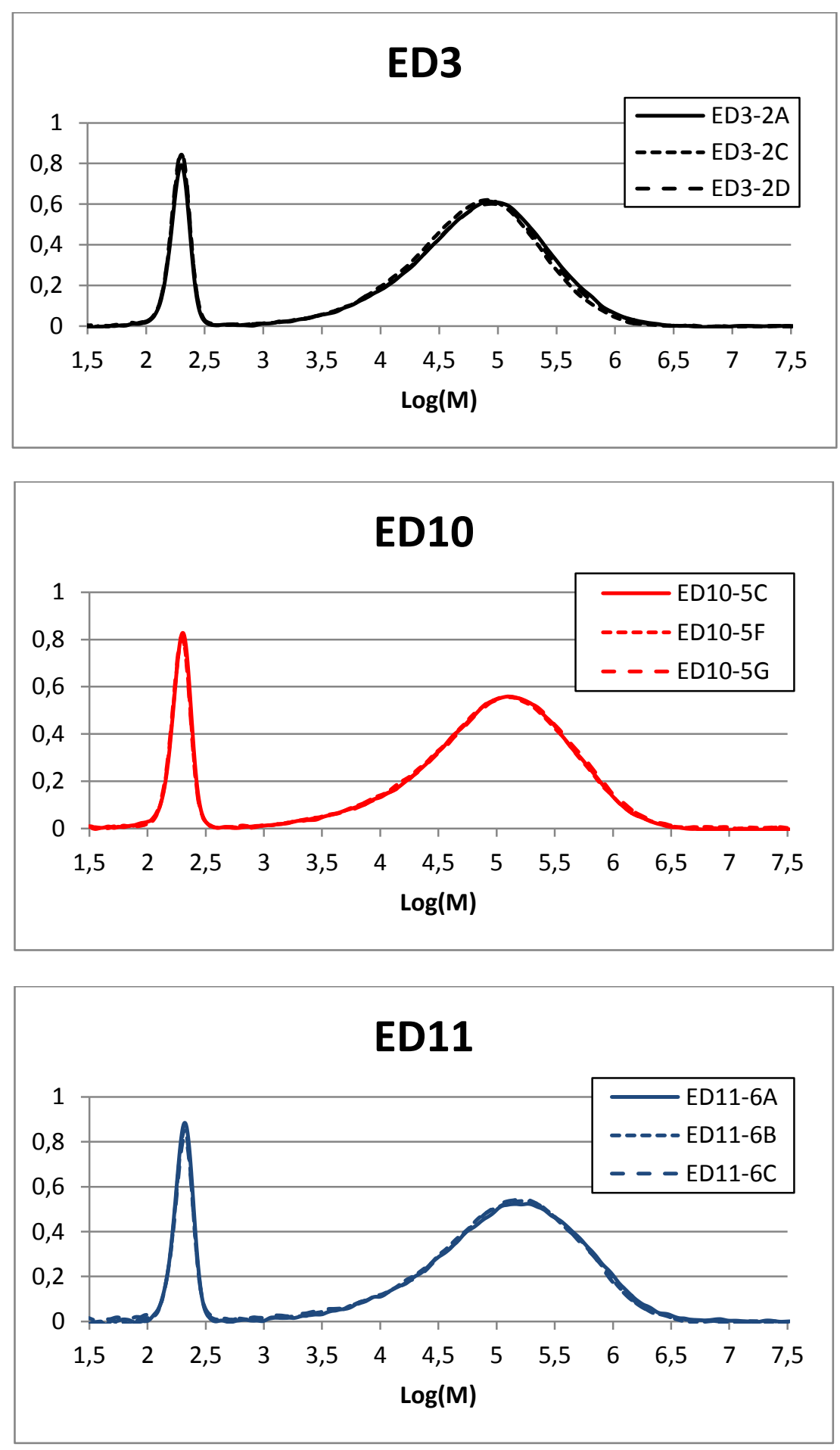

Figure S1. Overlays of GPC traces for PP samples produced in three triplicate experiments of Table 6 (reaction cells are explicitly indicated). The peak to the low MW side is due to the BHT stabilizer. 

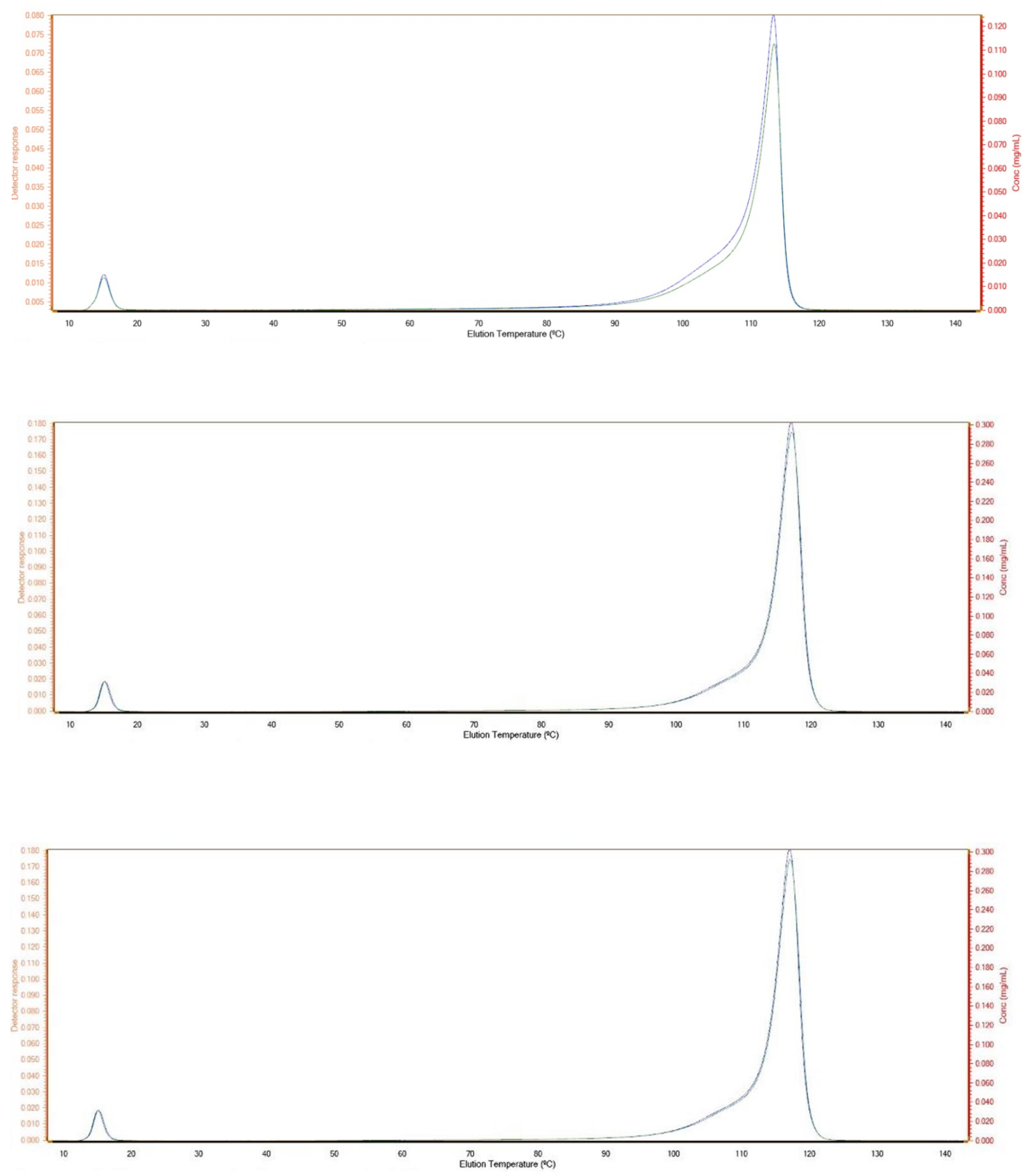

Figure S2. Overlays of CEF traces for pairs of PP samples produced in three triplicate experiments of Table 6. From top to bottom: ED3-cell2A (green) and ED3-cell2C (blue); ED10-cell5D (green) and ED10-cell5F (blue); ED11-cell6A (green) and ED11-cell6B (blue). 